\title{
EFEKTIVITAS BOOKLET DAN WONDERSHARE VIDEO DALAM MENINGKATKAN PENGETAHUAN DAN PERILAKU JUMANTIK-PSN DAN ANGKA BEBAS JENTIK PADA SMP NEGERI KECAMATAN JEKAN RAYA KOTA PALANGKA RAYA
}

\author{
Effectiveness Of The Use Of Wondershare Video And Booklets In Improving \\ Jumantik-Psn Behavior Of School Children And Larva Free Numbers In The \\ SMPN, Jekan Raya District, Palangka Raya City
}

\author{
Natalansyah ${ }^{\text {* }}$ \\ *I Poltekkes Kemenkes \\ Palangkaraya, Palangka Raya, \\ Kalimantan Tengah, Indonesia
}

*email: natalansyah@yahoo.co.id

Kata Kunci:

Wondershare

Video booklet

Jumantik- PSN

\section{Keywords:}

Video booklet

Behavior

Jumantik-PSN

\begin{abstract}
Abstrak
Penyakit menular utama yang menjadi masalah kesehatan masyarakat di Indonesia adalah Demam Berdarah Dengue (DBD). Indeks Rate DBD Kota Palangka Raya selama tiga tahun terus meningkat dan menjadi $68 \%$ dan CFR $2 \%$ ditahun 2018 , hal ini disebabkan peran serta masyarakat dalam kegiatan PSN belum optimal. Langkah strategis untuk mengoptimal peran serta masyarakat dalam pencegahan dan pengendalian DBD adalah pemberdayaan peserta didik dengan menggunakkan booklet dan media video dalam meningkatkan pengetahuan serta perilaku JumantikPSN anak sekolah.

Tujuan penelitian ini untuk mengetahui perbedaan penggunaan media WonderShare video dengan booklet dalam meningkatkan perilaku jumantik-PSN anak sekolah dan angka bebas jentik di SMP Negeri 9 dan 16 wilayah Puskesmas Kayon Kecamatan Jekan Raya Kota Palangka Raya.

Metoda Penelitian ini menggunakan desain eksperimental Two group pre and posttest design Sampel berjumlah 50 orang siswa SMPN kelas 7 \& 8, masing-masing 25 kelompok media video dan booklet, instrumen yang digunakan berupa WonderShare video, booklet, kuesioner, lembar cheklist.

Hasil penelitian menunjukan bahwa Uji independent t-test - terdapat perbedaan peningkatan rata-rata skore, Pengetahuan dan angka bebas jentik antara kelompok video dengan booklet : $\mathrm{P}=0,04 \mathrm{I}$ dan $\mathrm{P}=0,00 \mathrm{I},(\mathrm{P}<0,5)$.

Kesimpulan : Media video efektif dalam meningkatkan pengetahuan Jumantik-PSN Anak Sekolah dan menurunkan angka bebas jentik.
\end{abstract}




\section{PENDAHULUAN}

Penderita Demam Berdarah Dengue (DBD) tahun 2015 dilaporkan 129.650 kasus dengan jumlah kematian I.07I orang, IR 50,75/100.000 penduduk dan CFR: 0,83\% terjadi peningkatan dibandingkan dengan tahun 2014 dengan jumlah kasus 100.347 orang serta IR : 39,80\%. Jumlah area penyebaran bertambah dan meningkat kasus tahun 2014: 433 kabupaten menjadi 446 kabupaten, sedangkan pada tahun 2017 kasus DBD berjumlah 68.407 kasus, dengan jumlah kematian sebanyak 493 orang. Jumlah tersebut menurun cukup drastis dari tahun sebelumnya, yaitu 204.I7I kasus dan jumlah kematian sebanyak I.598 orang. Angka kesakitan DBD tahun 2017 menurun dibandingkan tahun 2016, yaitu dari 78,85 menjadi 26,10 per 100.000 penduduk. Namun, penurunan case fatality rate (CFR) dari tahun sebelumnya tidak terlalu tinggi, yaitu $0,78 \%$ pada tahun 2016, menjadi 0,72\% pada tahun 2017 (Kemenkes RI, 2018).

Insident Rate (IR) DBD cenderung meningkat dari 62\% per 100.000 penduduk pada tahun 2016 kemudian bertambat menjadi $64 \%$ per 100.000 penduduk tahun 2017 dan pada 2018 meningkat lagi $68 \%$ per 100.000 penduduk, dan berada diatas angka kesakitan nasional sebesar $<49 \% / 100.000$ penduduk. Kalteng termasuk 10 provinsi yang memiliki CFR DBD tinggi dimana 3 provinsi dengan CFR tertinggi adalah Kalimantan Selatan (2,18\%), Kalimantan Tengah (I,55\%), dan Gorontalo (I,47\%) (Dinkes Prop, 2018).

Kota Palangka Raya jumlah kasus sebanyak I56 orang (2017) dan 356 orang (2018) dengan 7 orang meninggal, Wilayah kerja Puskesmas, terbanyak 93 kasus dan 2 orang meninggal terdapat di wilayah Puskesmas Kayon Kecamatan Jekan Raya Kota Palangka Raya (Dinkes Kota, 2019).

Berbagai metoda dan media pendidikan secara konvensional telah banyak digunakan dalam meningkatkan pengetahuan, sikap, dan perilaku Jumantik -PSN anak agar dapat berperan dalam mengendalian
DBD seperti ceramah, audio Visual, leaflet dan booklet, sebagai sarana penunjang, yang dapat merangsang pikiran, perasaan, perhatian, dan minat dari penerima materi. Hasil penelitian (D.R.Fitriastutik, 2009) menunjukkan bahwa penggunaan booklet lebih efektif dibandingkan permainan tebak gambar dalam meningkatkan pengetahuan mengenai karies gigi pada siswa kelas 6 di beberapa sekolah dasar di Jepara. Penelitian lain yang dilakukan oleh (Lutfi Wahyuni, 20I5), bahwa Pemberian Pendidikan Kesehatan dengan media Booklet tentang bahaya merokok efektif terhadap tingkat pengetahuan pada remaja kelas VII di SMP I Mojoanyar.

Hasil penelitian terbaru mencatat pengguna internet dilndonesia yang berasal dari kalangan anakanak dan remaja diprediksi mencapai 30 juta, Studi ini menelusuri aktitas online dari sampel anak dan remaja yang berusia 10 sampai 19 tahun di seluruh Indonesia dan mewakili wilayah perkotaan dan pedesaan, sebanyak 98 persen dari anak dan remaja mengaku tahu tentang internet dan 79,5 persen di antaranya adalah pengguna internet (Kompas.com, 2019 ).

Aplikasi WhatsApp merupakan Smartphone yang digunakan dalam penyampaian pesan secara online, berbagi file, bertukar foto, WonderShare video dan lainlain. Media Wonder-Share Video efektif dalam meningkatkan pengetahuan, sikap, perilaku oleh Jumantik-PSN Anak Sekolah pada SMP Negeri Kecamatan Jekan Raya Kota Palangka Raya. Penelitian (Yongwan Nyamin, dkk 2018)

\section{METODOLOGI}

Penelitian ini adalah eksperimen tidak murni dengan kelompok kontrol (pretest-posttest with control group design) kelompok kontrol dan kelompok eksperimen dilakukan secara random. Pretest dilakukan pada kelompok tersebut dan diikuti intervensi kelompok eksperimen.

Populasi dilakukan pada 2 (dua) Sekolah Menengah Pertama yang memenuhi kriteria inklusi dan eklusi, pengumpulan data 
dengan kuesioner yang telah dilakukan uji coba Instrumen pada 25 s.d 30 Siswa Sekolah Menengah Pertama dan telah dilakukan analisa tingkat validitas dan reliabilitas dalam penelitian Yongwan Nyamin, dkk (2018); Lembar Observasi (Kartu Pemantau jentik); WonderShare video jumantik-PSN anak sekolah.

Analisa data dilakukan untuk mengetahui perbedaan perilaku dan keberadaan jentik sebelum dan sesudah pelatihan murid Jumantik-PSN pada kelompok eksperimen, perbedaan perilaku dan keberadaan jentik tanpa ada pelatihan murid jumantik-PSN pada kelompok kontrol dan perbedaan perilaku dan keberadaan jentik pada kelompok eksperimen dan kelompok kontrol. Selanjutnya dilakukan uji statistik yaitu Uji beda (McNemar) pada kelompok Booklet dan Kelompok Wondeshare Video, untuk mengetahui perilaku dan keberadaan jentik pretest dan postest kelompok penelitian yaitu kelompok eksperimen dan kontrol. Perbedaan Perilaku dan keberadaan jentik pada kelompok Booklet dan kelompok Wonder Share Video menggunakan Uji Chi-Square.

Analisis Multivariat untuk melihat hasil kemaknaan perhitungan statistik digunakan chi square, melihat ada hubungan yang bermakna atau ada perbedaan sehingga penolakan terhadap hipotesa apabila nilai $P<0,05$. Sedangkan penerima terhadap hipotesa apabila nilai $P>0,05$. (tidak ada perbedaan atau tidak ada hubungan yang bermakna) uji statistik digunakan dalam penelitian ini $X^{2}$ (Uji chi square), pembanding, peluang dengan regresi logistik ganda (multiple logistic regresi) dengan tingkat kemaknaan yang digunakan adalah $95 \%$.

\section{HASIL DAN PEMBAHASAN}

\section{Gambaran Pemantauan Jentik}

Tabel I. Hasil Pemantauan jentik nyamuk pada kelompok WonderShare Video dan Booklet

\begin{tabular}{|l|l|l|l|l|l|}
\hline Kelompok & $\mathrm{n}$ & \multicolumn{3}{|l|}{ Minggu I } & Minggu 8 \\
& & $\begin{array}{l}(+) \mathrm{n} \\
(\%)\end{array}$ & $\begin{array}{l}(-) \mathrm{n} \\
(\%)\end{array}$ & $\begin{array}{l}(+) \mathrm{n} \\
(\%)\end{array}$ & $\begin{array}{l}(-) \mathrm{n} \\
(\%)\end{array}$ \\
\hline WSV & 25 & $\begin{array}{l}10 \\
(40 \%)\end{array}$ & $\begin{array}{l}15 \\
(60 \%)\end{array}$ & $\begin{array}{l}0 \\
(0 \%)\end{array}$ & $\begin{array}{l}25 \\
(100 \%)\end{array}$ \\
\hline Booklet & 25 & $\begin{array}{l}10 \\
(40 \%)\end{array}$ & $\begin{array}{l}15 \\
(60 \%)\end{array}$ & $\begin{array}{l}2 \\
(8 \%)\end{array}$ & $\begin{array}{l}23 \\
(92 \%)\end{array}$ \\
\hline
\end{tabular}

Berdasarkan tabel I. Hasil pemantauan jentik nyamuk Kelompok Wonder Share Video, pada minggu ke-I ditemukan $40 \%$ positif dan $60 \%$ negatif, sedangkan pada minggu ke-8 ditemukan $0 \%$ positif dan 100\% negatif.
Pada kelompok booklet, hasil pemantauan jentik nyamuk pada minggu ke-I ditemukan sebanyak $40 \%$ positif dan $60 \%$ negatif, sedangkan pada minggu ke-8 ditemukan $8 \%$ positif dan $92 \%$ negatif.

Hasil penelitian ini berbeda dengan penelitian Abdulah Rachman Rosidi dan Wiku Adisasmito (2009) menyebutkan bahwa pelaksanaan pemantauan jentik secara berkala mampu meningkatkan angka bebas jentik $(A B J)$ di kecamatan Sumberjaya Kabupaten Majalengka Jawa Barat. Menurut Kemenkes (2016) dalam melakukan pemantauan jentik berkala (PJB) minimal 3 bulan akan mampu memotivasi masyarakat dalam melaksanakan PSN 3M Plus. Salah satu alasan mengapa tidak ada perbedaan $A B J$ karena Kegiatan pemantauan jentik yang dilakukan siswa SMPN 9 dengan WonderShare vidio dan siswa SMP 16 dengan booklet dilaksanakan selama 8 minggu (2 Bulan).

\section{Perbedaan pengetahuan dan Perilaku sebelum dan sesudah pada kelompok perlakuan dengan WonderShare Video.}

Tabel 2. Perbedaan Pengetahuan dan Perilaku sebelum dan sesudah Pemberian Wonder Share Video

\begin{tabular}{|c|c|c|c|c|c|c|}
\hline Data & $\begin{array}{l}\text { Rata- } \\
\text { rata } \\
\text { skor }\end{array}$ & $\begin{array}{l}\text { Standar } \\
\text { Deviasi }\end{array}$ & $\begin{array}{c}\text { Minimum } \\
- \\
\text { Maksimum }\end{array}$ & $\begin{array}{c}\text { Mean } \\
\text { Difference }\end{array}$ & $\begin{array}{l}95 \% \\
\mathrm{HCl}\end{array}$ & $\begin{array}{c}P \\
\text { Value }\end{array}$ \\
\hline $\begin{array}{l}\text { Pengetahuan } \\
\text { Sebelum }\end{array}$ & 8,28 & 1,67 & $5-11$ & \multirow[t]{2}{*}{2,56} & \multirow[t]{2}{*}{$\begin{array}{l}1,53- \\
3,58\end{array}$} & \multirow[t]{2}{*}{0,005} \\
\hline $\begin{array}{l}\text { Pengetahuan } \\
\text { Sesudah }\end{array}$ & 9,44 & 2,63 & $5-13$ & & & \\
\hline $\begin{array}{l}\text { Perilaku } \\
\text { Sebelum } \\
\end{array}$ & 3,36 & I, 70 & $1-6$ & \multirow[t]{2}{*}{1,48} & \multirow[t]{2}{*}{$\begin{array}{l}0,62- \\
2,34\end{array}$} & \multirow[t]{2}{*}{0,002} \\
\hline $\begin{array}{l}\text { Perilaku } \\
\text { Sesudah }\end{array}$ & 4,84 & 1,34 & $2-6$ & & & \\
\hline
\end{tabular}

Berdasarkan tabel 2. diketahui bahwa Pada kelompok perlakuan wonder share video, rata-rata pengetahuan sebelum pemberian Wonder share video yaitu 8,28 dengan nilai terendah 5 dan tertinggi II. Setelah pemberian Wonder share video, rata-rata pengetahuan 9,44 dengan nilai terendah 5 dan tertinggi 13. Hasil Analisa statistic menunjukkan terdapat perbedaan signifikan skor pengetahuan antara sebelum dan sesudah perlakukan Wonder share video, dengan perbedaan ratarata skor sebesar 2,56. 
Sukiman (2012) Media video adalah seperangkat komponen atau media yang mampu menampilkan gambar sekaligus. Video merupakan media yang cocok untuk pelbagai pembelajaran, seperti kelas, kelompok kecil, bahkan satu siswa seorang diri sekalipun. Hasil analisis dalam penelitian ini menunjukkan terdapat perbedaan rata-rata skor pengetahuan, antara sebelum dan sesudah intervensi, Perbedaan berupa peningkatan dari nilai rerata sebelum intervensi 8,15 menjadi 9,35 setelah intervensi dengan P.value: $0,027(p<0,05)$. Hasil penelitian ini sejalan dengan penelitian Lia Kurniasasi, dkk 2017 bahwa ada pengaruh media video terhadap pengetahuan ( $p$-value 0,25), dan didukung pendapat Dwiyogo, Wasis D. (2013) Pada ranah kognitif. Melalui Media Wonder share Video pembelajar-siswa bisa mengobservasi kejadian sejarah masa lalu dan rekaman aktual dari peristiwa terkini, karena unsur warna, suara dan gerak mampu membuat karakter terasa lebih hidup. Selain itu menonton video, setelah atau sebelum membaca, dapat memperkuat pemahaman siswa terhadap materi ajar. Materi ajar yang dimaksud disini yaitu bahan edukasi terhadap juru pemantau jentik (Jumantik)-PSN anak sekolah.

Kelompok perlakuan wonderShare video, rata-rata perilaku sebelum pemberian WonderShare video yaitu 3,36 dengan nilai terendah I dan tertinggi 6. Setelah pemberian WonderShare video, rata-rata perilaku 4,84 dengan nilai terendah 2 dan tertinggi 6. Hasil Analisa statistik menunjukkan perbedaan signifikan skor perilaku antara sebelum dan sesudah perlakukan WonderShare video dengan $\mathrm{P}$ value 0,002. Perbedaan rata-rata skor perilaku sebesar I,48.

Marquis dan Huston (2013) menyatakan pelatihan sebagai metode untuk menjamin bahwa seseorang mempunyai pengetahuan dan ketrampilan khusus yang diperlukan untuk melakukan tugas. Perilaku merupakan hasil pengalaman dan proses interaksi dengan lingkungannya, yang terwujud dalam bentuk pengetahuan, sikap dan tindakan sehingga diperoleh keadaan seimbang antara kekuatan pendorong dan kekuatan penahan. Hasil penelitian ini sejalan Penelitian Indah Suryani (2012) disimpulkan bahwa video pembelajaran menggunakan model problem solving berbantu Wonder share valid (layak menurut ahli) lebih efektif dari pada pembelajaran konvensional. berbeda dengan penelitian Siti Munadziron (20II) bahwa tidak ada perbedaan yang bermakna praktek petugas kebersihan sebelum dan sesudah dilakukan penyuluhan. $\mathrm{Hal}$ ini dikarenakan kesadaran responden masing kurang tentang manfaat mereka melakukan PSN dengan benar dan penyuluhan hanya dilakukan sekali.

\section{Perbedaan pengetahuan dan Perilaku antara kelompok Wondershare Video dan Booklet.}

Tabel 3. Perbedaan Pengetahuan dan Perilaku antara Pemberian Wonder Share Video (WSV) dan booklet

\begin{tabular}{|c|c|c|c|c|c|c|c|}
\hline Data & $\begin{array}{l}\text { Rata- } \\
\text { rata } \\
\text { skor }\end{array}$ & $\begin{array}{l}\text { Standar } \\
\text { Deviasi }\end{array}$ & $\begin{array}{l}\text { Min- } \\
\text { Mak }\end{array}$ & $\begin{array}{l}\text { Levene } \\
\text { Test }\end{array}$ & $\begin{array}{c}\text { Mean } \\
\text { Difference }\end{array}$ & $\begin{array}{l}95 \% \\
\mathrm{HCl}\end{array}$ & $\begin{array}{c}P \\
\text { Value }\end{array}$ \\
\hline $\begin{array}{l}\text { Pengetahuan } \\
\text { WSV }\end{array}$ & 10,84 & 2,05 & $6-15$ & \multirow[t]{2}{*}{0,055} & \multirow[t]{2}{*}{1,40} & \multirow[t]{2}{*}{$\begin{array}{l}0,05- \\
2,74\end{array}$} & \multirow[t]{2}{*}{0,041} \\
\hline $\begin{array}{l}\text { Pengetahuan } \\
\text { booklet }\end{array}$ & 9,44 & 2,63 & $5-13$ & & & & \\
\hline $\begin{array}{l}\text { Perilaku } \\
\text { WSV }\end{array}$ & 4,84 & 1,34 & $2-6$ & \multirow[t]{2}{*}{0,22} & \multirow[t]{2}{*}{-} & \multirow[t]{2}{*}{$\begin{array}{l}0,07- \\
1,67\end{array}$} & \multirow[t]{2}{*}{0,073} \\
\hline $\begin{array}{l}\text { Perilaku } \\
\text { booklet }\end{array}$ & 4,04 & $|, 7|$ & $0-6$ & & & & \\
\hline
\end{tabular}

Dari tabel 3. Hasil penelitian yang menunjukan bahwa rata-rata skor pengetahuan pada kelompok media wondershrae video sebesar 10,84 dengan nilai terendah 6 dan tertinggi 15. Sedangkan pada kelompok media booklet, rata-rata skor pengetahuan yaitu 9,44 dengan nilai terendah 5 dan tertinggi I 3 dengan perbedaan ratarata skor pengetahuan sebesar I,4. Hal ini dinyatakan dengan $P$ value: $0,04 I .(P<0,5)$ Terdapat perbedaan signifikan rata-rata skor pengetahuan antara kelompok WonderShare video dan kelompok booklet dengan $\mathrm{P}$ value $0,04 I$. Hasil penelitian ini bermakna bahwa media WonderShare video lebih efektif dibandingakan dengan media booklet dalam meningkatkan pengetahuan Jumantik-PSN anak sekolah dengan rerata 10,84. Hasil Penelitian ini sejalan penelitian Winda Ismawati ((20l8) bahwa media yang paling efektif untuk meningkatkan 
pengetahuan adalah Video dengan peningkatan pengetahuan $18 \%$ serta pengaruh dengan media video( $(P=0,000)$. Hasil Penelitian lain yang mendukung penelitian Jusup Kristianto dkk (2018) menunjukkan bahwa ada perbedaan terhadap peningkatan kebersihan gigi dan mulut antara kelompok yang diberikan. Intervensi video dengan WhatsApp dan kelompok yang tidak diberikan WhatsApp, di mana $P=0,001(P<$ 0,05,). Sedangkan hasil penelitian yang berbeda yaitu Lutfi Wahyuni (2016) bahwa Pemberian Health Education dengan media Booklet tentang bahaya merokok efektip terhadap tingkat pengetahuan bahaya merokok pada remaja dengan signifikan $p$ value $=0,00$ $(p<0,5)$. Hasil penelitian Maria Agustin dkk (20l4) menyatakan bahwa terdapat perbedaan pengetahuan antara sebelum dan sesudah pendidikan karier gigi pada responden dengan media booklet $P$.value $=0,000$. Selisih hasil analisa pengetahuan Jumantik-PSN anak sekolah antara media WonderShare Video disebabkan karena karakteristik dana proses penyampaian informasi kedua media tersebut berbeda. Video merupakan media audiovisual yang mengandalkan indra penglihatan dan pendengaran dalam menangkap informasi yang didapatkan. Pemilihan Wonder share video media pendidikan kesehatan pada Jumantik-PSN anak sekolah dapat diterima dengan baik oleh peserta didik sebagai responden, media ini memberikan penyuluhan dengan menarik dan tidak monoton. Pada media Video menampilkan gambar gerak dan suara mampu memberikan gambaran yang lebih jelas dan dapat meningkatkan pemahaman (Farudin Ahmad, 20ll). Booklet sebagai media visual hanya mengandangkan indera penglihatan, menurut Dale dalam A. Arsyad (20I2) dimana pengalaman belajar hanya membaca saja daya serapnya hanya 10\%. Pada media booklet responden mendapat materi hanya dari visual saja tanpa gerakana sehingga materi yang diberikan relative kurang menarik dan kemampuan menyerap pengetahuan.

Hasil penelitian ini menunjukan bahwa Rata-rata skor perilaku pada kelompok wondershrae video sebesar
4,84 dengan nilai terendah 2 dan tertinggi 6. Sedangkan pada kelompok booklet, rata-rata skor perilaku yaitu 4,04 dengan nilai terendah 0 dan tertinggi 6. Tidak terdapat perbedaan signifikan rata-rata skor perilaku antara kelompok WonderShare video dan kelompok booklet dengan $P$ value 0,073 . $(P>0,5)$. Hasil penelitian sejalan pendapat Dwiyogo, Wasis D, (2013) video memberikan kesempatan pada mereka untuk mendiskusikan apa yang telah mereka saksikan secara bersama lebih dari itu, manfaat karakteristik lain dari media video atau film dalam meningkatkan efektivitas dan efisiensi proses pembelajaran karena video memiliki potensi besar untuk pengaruh emosional, maka video sangat berguna dalam membentuk perilaku individu dan perilaku sosial.

\section{Perbedaan keberadaan jentik antara} kelompok media video dan media booklet.

Tabel 4. Analisis Perbedaan Angka Keberadaan Jentik sebelum dan sesudah Masa intervensi media Video dan booklet

\begin{tabular}{|l|l|l|l|}
\hline $\mathrm{N}$ & Hasil - & Hasil + & PValue \\
\hline $\begin{array}{l}\text { Media WSH Video } \\
(\mathrm{n}=25)\end{array}$ & $\begin{array}{l}25 \\
(100 \%)\end{array}$ & $0(0 \%)$ & \multirow{2}{*}{0,490} \\
\cline { 1 - 3 } $\begin{array}{l}\text { Media Booklet } \\
(\mathrm{n}=25)\end{array}$ & $\begin{array}{l}23 \\
(92 \%)\end{array}$ & $2(8 \%)$ & \\
\hline
\end{tabular}

Hasil analisis menunjukkan kelompok Wondershare video sebanyak 100\% angka bebas jentik negatif sedangkan kelompok booklet menunjukkan 92\% angka bebas jentik negatif. Uji statistik menunjukkan tidak ada perbedaan proporsi $A B J$ antara media WonderShare video dan booklet dinyatakan dengan $\mathrm{p}$ value 0,490 . yang artinya tidak terdapat perbedan keberadaan jentik di lingkungan rumah yang siswa jumantik yang menggunakan media WonderShare dengan lingkungan rumah yang siswa yang media edukasi Booklet pada SMP Negeri di lingkungan kelurahan Bukit Tunggal Palangka Raya. Hasil ini berbeda dengan penelitian Ayu Wandini (20I3) menggunakan uji Fisher menunjukan significancy $0,007(p<0,05)$ bahwa terdapat perbedaan keberadaan jentik di sekolah dasar yang terdapat siswa pemantau jentik aktif dengan sekolah dasar yang tidak terdapat siswa pemantau jentik aktif di Sekolah Dasar Kecamatan gajah mungkur tahun 2013. Hasil penelitian 
lain yang mendukung yaitu Achmad Fachirizal, dkk (2006) pemberdayaan siswa pemantau jentik dapat peningkatkan angka bebas jentik dari $7 \%$ menjadi $96 \%$ sesudah pelatihan kesehatan. Salah satu penyebab mengapa tidak ada perbedaan $A B J$ karena Kegiatan pemantauan jentik yang dilakukan siswa SMPN 9 dengan Wonder share vidio dan siswa SMP 16 dengan booklet dilaksanakan selama 8 minggu (2 Bulan).

\section{KESIMPULAN}

I. Terdapat perbedaan rata-rata skor pengetahuan sebelum dan sesudah perlakuan dengan WonderShare Video Jumantik-PSN anak sekolah dengan $P$ Val.0,005 $(<0,05)$

2. Secara statistik terdapat perbedaan rata-rata skor perilaku sebelum dan sesudah perlakuan dengan WonderShare Video Jumantik-PSN anak sekolah ,P Val.0,002 $(<0,05)$

3. Bahwa tidak ada perbedaan rata-rata skor angka keberadaan jentik sebelum dan sesudah perlakuan dengan WonderShare Video Jumantik-PSN anak sekolah P Value.0,002 $(<0,05)$

4. Bahwa ada terdapat Perbedaan signifikan rata-rata skor pengetahuan antara kelompok WonderShare dan kelompok booklet dengan $\mathrm{P}$ value $0,4 \mathrm{I}(<0,5)$

5. Bahwa tidak terdapat Perbedaan signifikan rata-rata skor perilaku antara kelompok WonderShare dan kelompok booklet dengan $\mathrm{P}$ value $0,073(>0,5)$

6. Bahwa tidak terdapat Perbedaan signifikan rata-rata skor angka bebas jentik antara kelompok WonderShare dan kelompok booklet dengan $P$ value $0,490(>0,5)$

\section{UCAPAN TERIMA KASIH}

Berisi Informasi ucapan terima kasih serta penghargaan kepada pihak-pihak yang telah berpartisipasi dalam kegiatan penelitian yang dilakukan. Bisa kepada institusi penyedia anggaran maupun hibah (mencantumkan sumber dan skema hibah yang digunakan), pihak institusi tempat kegiatan penelitian dilakukan, narasumber, organisasi dan unsur masyarakat, serta sivitas akademika yang telah membantu pelaksanaan kegiatan penelitian.

\section{REFERENSI}

I. Kemenkes RI, 20I8. Inciden Rate (IR) Angka Bebas Jentik di Indonesia Tahun 2010-2017

2. Dinkes Propinsi, 2018 Profil Dinas Kesehatan Propinsi Kalimantan Tengah

3. Dinkes kota, 2019 Profil Dinas Kesehatan Kota Palangka Raya

4. Diah Ratna Fitriastutik, 2009 Efektivitas Booklet dan Permainan Tebak Gambar dalam Meningkatkan Pengetahuan dan Sikap Siswa Kelas IV terhadap Karies Gigi di SD Negeri 0I, 02 dan 03 Bandengan Kecamatan Jepara Kabupaten Jepara Tahun Ajaran 2009/2010

5. Lutfi Wahyuni,20I4, Efektivitas Health Education (HE) media Booklet tentang Bahaya Rokok terhadap tingkat pengetahuan Remaja di SMP I Mojoanyar

6. Kompas.com, 2019 Pengguna internet di Indonesia yang berasal dari kalangan anak-anak dan remaja

7. Yongwan Nyamin dan Natalansyah, 2017 Peranan Booklet terhadap peningkatan Perilaku JumantikPSN anak sekolah dan Keberadaan Jentik di Kelurahan Panarung Kota Palangka Raya

8. Rosidi, Abd. Rachman dan Wiku Adi Sasmito, 2009, Hubungan Faktor Penggerakan Pemberantasan Sarang Nyamuk Demam Berdarah Dengue (PSN DBD) dengan Angka Bebas Jentik di Kecamatan Sumberjaya Kabupaten Majalengka, Jawa Barat, diakses 10 Januari 20I3,

9. Kemenkes RI, 2016 Pemantauan Jentik nyamuk dan PSN 3M Plus

10. Sukiman, 20I2. Pengembangan Media Pembelajaran. Yogyakarta: PT Pustaka Insan Madani

II. Kurniasari Lia dan Al Wardani, 2017 Pengaruh Media Video Terhadap Pengetahuan Dalam Upaya Pencegahan Perilaku Seks Pranikah pada Siswa

12. Dwiyogo, Wasis D, 2013 Media Pembelajaran, Malang Wineka Media

13. Marquis, B.L. \& Huston, C.J. 2013, Kepemimpinan dan Manajemen Keperawatan: Teori dan Aplikasi. Edisi keempat. Jakarta: EGC.

I4. Indah Suryani, 2012 video pembelajaran menggunakan model problem solving

15. Siti Munadziroh, 201I Perbedaan pengetahuan dan praktik petugas kebersihan sekolah dasar sebelum dan sesudah penyuluhan pemberantasan sarang nyamuk demam berdarah dengue di kecamatan tembalang kota semarang

16. Ismawati Winda dan Kristien Andriani, SKM, M.Si, 2018 Efektifitas Penggunaan Media Leaflet, Buku Saku, Video Untuk Meningkatkan Pengetahuan 
Pemberian Makanan Pendamping Air Susu Ibu (MP Asi) Di Desa Kenep Kecamatan Sukoharjo. Skripsi thesis, Universitas Muhammadiyah Surakarta.

17. Jusuf Kristianto, Dwi Priharti, Abral, 2018 Efektifitas Peyuluhan Kesehatan Gigi Dan Mulut Dengan Media Video Melalui WhatsApp Dalam Meningkatkan Derajat Kesehatan Gigi Dan Mulut Di Panti Asuhan Yos Sudarso Jakarta

18. Lutfi Wahyuni, 2014 Efektivitas Health Education (HE) media Booklet tentang Bahaya Rokok terhadap tingkat pengetahuan Remaja di SMP I Mojoanyar.

19. Maria Agustin, 2014, Efektifitas Pendidikan Kesehatan Media Booklet Dibandingkan Audiovisual Terhadap Pengetahuan Orang Tua Tentang Karies Gigi Pada Anak Usia 5-9 Tahun Di Desa Makamhaji

20. Farudin ahmad, 20II Pengaruh pendidikan kesehatan dengan media audiovisual dan media booklet terhadap sikap caregiver dalam mencegah penularan tuberkulosis pada anggota keluarga

2I. Arsyad, A, 2012 Media Komunikasi Pendidikan. Jakarta

22. Ayu Wandini, 2013 Keberadaan jentik di sekolah dasar yang terdapat siswa pemantau jentik aktif dengan sekolah dasar yang tidak terdapat siswa pemantau jentik aktif di Sekolah Dasar Kecamatan gajahmungkur

23. Fahrizal, Achmad and Wijaya, Windi Ari and Efendi, Ferry and Hasanah, Kamalia, 2006 Pemberdayaan Siswa Pemantau Jentik (Wamantik) Sebagai Upaya Pencegahan Kejadian Luar Biasa (KLB) Demam Berdarah Dengue. Online),(http://www. infodiknas. com, diakses 28 Maret 20I2). 